\title{
Ketogenic Diet for Refractory Childhood Epilepsy: Beyond Seizures Control, the Experience of a Portuguese Pediatric Centre
}

\author{
Dieta Cetogénica na Epilepsia Infantil Refratária: \\ Para além do Controlo das Crises, Experiência \\ de um Centro Pediátrico Português
}

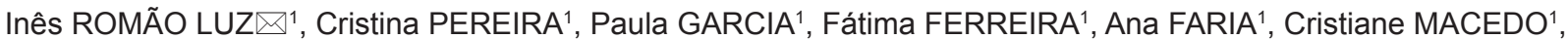 \\ Luísa DIOGO ${ }^{1}$, Conceição ROBALO ${ }^{1}$ \\ Acta Med Port 2019 Dec;32(12):760-766 - https://doi.org/10.20344/amp.12184
}

\section{ABSTRACT}

Introduction: Ketogenic diet is a low carbohydrate diet, which can be used as a treatment for refractory childhood epilepsy. The first aim of this study was to evaluate its efficacy, in patients receiving ketogenic diet for at least three months, on epilepsy control, behaviour and awareness. The secondary aims were to evaluate the variation in the number of antiepileptic drugs, reasons for discontinuing the diet and adverse effects.

Material and Methods: Retrospective analysis of clinical records of patients who underwent ketogenic diet for refractory epilepsy, from October 2007 to January 2018, in a tertiary pediatric hospital.

Results: In the twenty-nine eligible patients, the mean age of initiation was 7.9 years-old (+/- 5.6$)$. Of those, 18 had a $\geq 50 \%$ reduction of seizure activity, 19 a marked behaviour improvement and 18 improved awareness. The median number of antiepileptic drugs remained equal for the 15 patients who completed 18 months of treatment (three drugs). The main reason for discontinuing ketogenic diet was a familiar decision. The main adverse effects were hypercholesterolemia $(n=23)$ and hypertriglyceridemia $(n=21)$.

Discussion: Results were comparable to those of other cohorts, namely age of initiation, proportion of patients completing ketogenic diet, most frequent reasons for stopping and significant improvement of alertness and behavior.

Conclusion: Beyond seizure control, patients experienced a marked improvement in behavior and awareness. It is necessary to develop strategies to increase the adherence of families to the diet.

Keywords: Child; Diet, Ketogenic; Drug Resistant Epilepsy/diet therapy; Portugal

\section{RESUMO}

Introdução: A dieta cetogénica é uma dieta com baixo teor de hidratos de carbono, que pode ser usada no tratamento da epilepsia infantil refratária. O principal objetivo deste estudo foi avaliar a eficácia nos doentes que completaram pelo menos três meses de dieta, no que respeita ao controlo das crises, comportamento e estado de alerta. Foi também avaliada a variação do número de fármacos antiepiléticos, as razões de descontinuação e os efeitos secundários.

Material e Métodos: Análise retrospetiva dos processos clínicos dos doentes com epilepsia refratária sob dieta cetogénica, de outubro de 2007 a janeiro de 2018, num hospital pediátrico de nível 3.

Resultados: Nos 29 doentes elegíveis, a média da idade de implementação foi 7,9 anos (+/- 5,6). Destes, 18 tiveram uma redução $\geq 50 \%$ das crises, 19 tiveram uma melhoria marcada do comportamento e 18 do seu estado de alerta. Dos 15 que completaram 18 meses, a mediana do número de fármacos antiepiléticos permaneceu idêntica à do início (três fármacos). A principal razão de descontinuação foi por decisão familiar. Os principais efeitos secundários foram a hipercolesterolémia $(n=23)$ e a hipertrigliceridémia $(n=21)$.

Discussão: Os resultados foram semelhantes aos obtidos noutras coortes, nomeadamente no que respeita à idade de início, à percentagem de doentes que completou a dieta, às razões da suspensão e à melhoria do comportamento e estado de alerta.

Conclusão: Para além do controlo das crises, os doentes tiveram uma marcada melhoria do seu comportamento e estado de alerta. É necessário desenvolver estratégias para aumentar a adesão das famílias à dieta.

Palavras-chave: Criança; Epilepsia Resistente a Medicamentos/dietoterapia; Portugal

\section{INTRODUCTION}

Refractory or pharmacoresistant epilepsy can be defined as epilepsy that does not respond to two or more antiepileptic drugs and represents $20 \%$ to $30 \%$ of childhood epilepsies. After a period of residual use due to the explosion of new antiepileptic drugs (AED), ketogenic diet (KD) was reborn as a useful treatment tool for these patients. Besides the indication for specific inborn errors of metabolism, there is growing evidence that KD therapies are useful not only in this subset of epilepsies but also in cancer, traumatic brain injury, Alzheimer and Parkinson diseases and autism spectrum disorders. ${ }^{1,2}$

$\mathrm{KD}$ is a high-fat, low-carbohydrate diet, nowadays with different modalities like classic and modified KD and medium-chain triglycerides, low glycemic index and modified Atkins diets (the last two being more used in adults). ${ }^{3}$ In refractory childhood epilepsy and epileptic encephalopathy $(E E)$, the classic KD has more evidence of efficacy but the others, less restrictive, are gaining space. ${ }^{4,5}$

\footnotetext{
1. Centro de Desenvolvimento da Criança. Hospital Pediátrico. Centro Hospitalar e Universitário de Coimbra. Coimbra. Portugal.

$\triangle$ Autor correspondente: Inês Luz. inesluz1988@gmail.com

Recebido: 13 de abril de 2019 - Aceite: 21 de junho de 2019 | Copyright @ Ordem dos Médicos 2019
} 
Although the exact mechanism of action is not completely clarified, KD seems to act through different and synergistic pathways involving neurotransmitters, ion channel regulation, bioenergetics and mitochondrial changes. ${ }^{6,7}$

There are recommendations from the International League Against Epilepsy (ILAE) and the International Ketogenic Diet Study Group, which allow the improvement and adaptation of local guidelines. Similar protocols make the results of KD therapy more comparable. ${ }^{8-10}$ Recently, a multidisciplinary group of experts published specific guidelines for infants, paying attention to the particular nutritional and developmental needs of this age group. ${ }^{11}$ However, there is still lack of connection between the different centres, even within countries, and also of multicentre studies in order to define which epilepsy types would respond better to KD.1,12 Other points of discussion are the minimum period of time required to expect a positive response to KD (although a three month period is somewhat consensual) and the appropriate time to carry out the diet's weaning process, since doing it at 18 or 24 months is not considered adequate by some centres. Besides, there are a few randomized controlled trials in which one of the arms includes epileptic patients under KD. ${ }^{1,10,12-14}$

In this observational retrospective study, our aim was to evaluate the efficacy of KD therapies in childhood refractory epilepsy/EE, considering the protocol followed at our institution regarding seizure reduction, awareness and behavior improvement. Secondary objectives were to evaluate the main reasons for discontinuation, acute and chronic complications and the repercussion on patients' AED schedule.

\section{MATERIAL AND METHODS}

\section{Subjects}

This study was conducted in a tertiary Portuguese pediatric hospital. Clinical charts from patients who begun KD between October 2007 and January 2018, were reviewed. Data were obtained until the end of April 2018.

The authors have followed the protocols of their work centre on the publication of data. The data was anonymized and none of the authors had access to patient identification.

The study is being conducted in accordance with the Helsinki Declaration.
Inclusion criteria were: 1) EE and refractory epilepsy (patients who maintain seizures despite optimal treatment with two or more AED) and 2) accomplishment of at least three months of diet.

Exclusion criteria were: 1) Diagnosed inherited metabolic diseases and 2) loss of follow-up or lack of adherence to the diet after the first three months period.

Twenty-nine patients were eligible as depicted in Fig.1.

\section{Local KD protocol}

Patients with refractory epilepsy, with recognized etiology or epileptic syndrome, are proposed to KD by the Neuropediatrics Epilepsy team. A meeting at the Metabolic Disease unit is scheduled, in order to explain KD and evaluate the capacity and motivation of the family to follow it. A complete medical and nutritional assessment is done. Diagnostic tests are also performed: glucose, albumin and pre-albumin, calcium, zinc, selenium, magnesium, chloride, ammonium, transaminases, urea, creatinine, uric acid, cholesterol, triglycerides, 25-OH-vitamine $\mathrm{D}$, blood acylcarnitines profile, blood gases, urinalysis with calcium/creatinine urine ratio, and tetrapolar bioelectric impedance exam. In order to select the type and initial ratio of KD therapy to implement, age, type of feeding, needs and preferences of the child and its family are considered. Usually KD is implemented in an inpatient setting, for three days, in a 2:1 to $3: 1$ ratio of lipids to carbohydrates plus proteins, in grams, with a close monitoring of acute complications. During this stay, parents are instructed on how to use Keto Diet Calculator®, to prepare the meals and to monitor ketonemia, glycemia and ketonuria. Follow-up appointments are scheduled at the Metabolic Diseases unit at days 7 to 15 and months 1, 3, $6,12,18$ and 24. Medical, nutritional and analytical assessments are made during outpatient visits, in order to assess efficacy and secondary effects. KD should be discontinued at 18 to 24 months if successful or at three months if unsuccessful. Suspension is gradual in two to three months. More recently, patients have been called for a visit after the complete weaning of the diet (end of the diet).

\section{Efficacy assessment}

Data analysis is presented concerning:

1) Epileptic activity - based on patients' diary (number

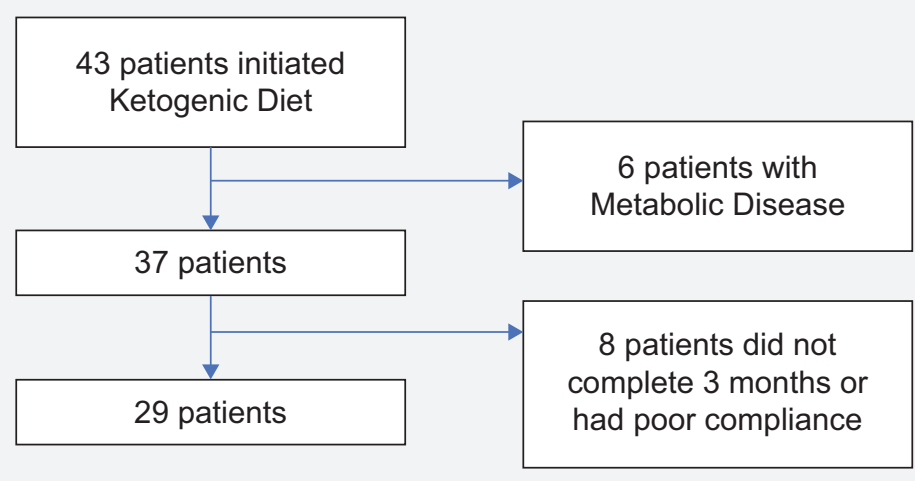

Figure 1 - Flow diagram of patients' selection 
and intensity of seizures throughout the KD) and in data obtained with awake and sleep electroencephalograms (6 months before and at 3, 6, 12, 18 and 24 months of KD). The outcome was classified in five groups: $100 \%$ seizure reduction or seizure free, from $90 \%$ to $99 \%$ seizure reduction, from $50 \%$ to $90 \%$ seizure reduction, less than $50 \%$ seizure reduction and no reduction. We defined efficacy in seizure control as a seizure reduction rate of $50 \%$ or higher, as reported by other groups ${ }^{14}$;

2) Behavior - a subjective measure, based in parents and clinicians' perception and information from school staff. The outcome was classified in three groups: marked improvement, moderate improvement and no improvement;

3) Awareness - equal to the previous item;

4) AED schedule - number of drugs at the beginning and at the end of KD of children who completed at least 18 months of KD.

\section{Secondary effects}

We searched for:

1) Acute effects, occurring in the first week of KD, namely: vomiting, nausea, acidosis, hypoglycemia, fever, food refusal, lethargy and mood change;

2) Chronic effects, occurring after the first week of KD: hyperlipidaemia, failure to thrive, constipation, electrolytic imbalances, hyperuricemia, carnitine and vitamin deficiencies, hepatitis, anemia and chronic infections.

\section{Reasons for discontinuation}

We also looked at reasons of discontinuation.

\section{Statistical analysis}

Descriptive analysis was performed using the 14.2 version of the STATA software (Copyright 1985-2015 StataCorp LP). Due to the small sample size no tests were performed.

\section{RESULTS}

\section{Demographics and KD implementation}

Twenty-nine patients were analyzed, corresponding to 17 males and 12 females, with a mean age of 7.9 years old at the beginning of $\mathrm{KD}(+/-5.6$ years old; range

Table 1 - Demographics and diet chronologies $(n=29)$

\begin{tabular}{lc}
\hline & $\begin{array}{c}\text { No. or mean } \\
(+/-S D ; \text { min }- \text { max }) \text { T }\end{array}$ \\
\hline Male & 17 \\
Age of beginning (years old) & $7.9(+/-5.6 ; 9 \mathrm{M}-18)$ \\
$<5$ & 11 \\
{$[5-10[$} & 8 \\
{$[10-15[$} & 5 \\
{$[15-20[$} & 5 \\
Hospital beginning & 25 \\
Days of hospitalization & $3.5(+/-1.43 ; 2-7)$ \\
Ceased the diet & 18 \\
Duration (M) & $18.2(+/-9.8 ; 3-36)$
\end{tabular}

M: months; max: maximum; min: minimum; No.: number; SD: standard deviation
9 months -18 years old) (Table 1$)$. The majority $(n=25)$ began their diet as inpatients, after elective admissions for this purpose, with a mean of 3.5 days of hospitalization (+/- 1.43 days; range $2-7$ ). Three started KD as outpatients: one had a brother who had already received $K D$, one was the second time he was initiating $K D$ and the third one due to family constraints. A 10-month female with febrile infection-related epilepsy (FIRES), started the $\mathrm{KD}$ in the Intensive Care unit, and was the only one who received ketogenic total parenteral nutrition. At discharge, $21 / 25(84 \%)$ were on a $2.5-3.0: 1$ ratio of fat to protein and carbohydrates KD, one was on a higher ratio and the other four on a less restrictive KD therapy.

When the analysis was carried out, 18/29 (62.1\%) had ceased the diet; the remaining eleven patients were still under KD. For those eighteen, the mean duration of the KD was 18.2 months (+/- 9.8 months; range $3-36)$. The retention rate at 12 months was $77.8 \%(n=14)$ and at 18 months $55.6 \%(n=10)$. Those who stopped between 3 to 18 months, did it due to: family choice $(n=5)$ and inefficacy $(n=3)$.

\section{Diagnosis}

Clinical diagnoses according to the International League Against Epilepsy (ILAE) classification of epilepsies and epileptic syndromes are listed in Table 2. The most common diagnoses were Lennox-Gastaut syndrome $(n=9)$ and West syndrome $(n=7)$.

Table 2 - Clinical diagnosis and known aetiologies of the 29 patients

\begin{tabular}{lc}
\hline Clinical diagnosis & No. (Total 29) \\
\hline - Lennox-Gastaut syndrome & 9 \\
Postinfectious & 3 \\
del 22q11.21 * & 1 \\
Focal cortical dysplasia type II & 1 \\
Multifocal cortical dysplasia & 1 \\
SYNGAP1 mutation * & 1 \\
No defined etiology & 2 \\
- West syndrome & 7 \\
Perinatal stroke & 2 \\
MCD * & 2 \\
PEHO syndrome * & 1 \\
MAGI 2 mutation * & 1 \\
Tetrasomy 15q & 1 \\
- Epilepsy with myoclonic-atonic seizures & 4 \\
- Ohtahara syndrome & 2 \\
Classic lissencephaly due to mutation & 1 \\
No defined etiology & 1 \\
- Myoclonic epilepsy in infancy & $\mathbf{2}$ \\
- Landau-Kleffner syndrome & $\mathbf{1}$ \\
- Dravet syndrome & $\mathbf{1}$ \\
- Focal epilepsy & 1 \\
Tuberous sclerosis complex & 1 \\
- Generalized absence epilepsy & $\mathbf{1}$ \\
\hline
\end{tabular}

*del: deletion; FIRES: febrile infection-related epilepsy syndrome; MAGI 2: membrane-associated Guanylate kinase Inverted 2; MCD: malformations of cortical development; PEHO: progressive encephalopathy with edema, hypsarrhythmia and optic atrophy; SYNGAP1: synaptic Ras GTPase activating protein 1 . 


\section{Efficacy assessment}

Concerning seizure control: four of the twenty-nine patients $(13.8 \%)$ became seizure free, four $(13.8 \%)$ had $\geq 90 \%$ reduction and nine (31\%) achieved a $50 \%-90 \%$ decrease. In short, there was $\geq 50 \%$ seizure reduction in seventeen patients (58.6\%). Regarding behavior and awareness, there was a marked improvement in eighteen $(62.1 \%)$ and in nineteen $(65.5 \%)$ patients, respectively.

Ten patients $(34.5 \%)$ completed the 18 months KD period: three became seizure-free, other five had a reduction $>50 \%$ of seizure activity, nine had a marked behavior improvement and five improved their awareness.

The effects of KD on seizure control, behavior and awareness according to the electroclinical syndrome are summarized in Table 3.

In five patients with malformations of the cortical development, a $50 \%$ - 90\% reduction in seizure frequency was achieved in three and two showed no improvement. Regarding behavior and awareness there was a marked improvement in three.

In those with a history of central nervous system infection $(n=3)$, there were distinct responses: two who had meningococcal meningitis became seizure free, with a marked improvement in behavior and awareness; one with herpes simplex virus encephalitis had no seizure improvement and there was a moderate impact on behavior and awareness.

The two patients with vascular events of the central nervous system had a moderate to marked behavior improvement.

The case of tuberous sclerosis complex had $<50 \%$ seizure reduction, with a moderate improvement on behavior and a marked effect on awareness.

The response to KD according to genetic mutations and chromosome abnormalities, already identified, are represented in Table 4.

Looking at the fifteen patients who completed at least 18 months of $\mathrm{KD}$, for $4 / 15(26.7 \%)$ there was a reduction of the number of AED (two with Lennox-Gastaut syndrome and two with epilepsy with myoclonic-atonic seizures), $10 / 15(66.7 \%)$ maintained the same number (four with Lennox-Gastaut syndrome, three with West syndrome, one with Ohtahara syndrome, one with Dravet syndrome and one with focal epilepsy) and in a case of Landau-Kleffner syndrome $(6.7 \%)$, there was the need to add one more AED. The median number of AED at the beginning was three, just like at the end of treatment.

\section{Adverse effects}

Acute complications were documented in twenty-six of the twenty-nine patients. The most frequent were hypoglycemia and nausea/vomiting, reported in six and five patients, respectively.

Chronic side effects were observed in all twenty-nine patients and were not responsible for diet discontinuation. Hypercholesterolemia presented in twenty-three (79.3\%) and hypertriglyceridemia in twenty-one $(72.4 \%)$ patients. Constipation was documented in nine (31\%), being de novo in one patient. Anemia was detected in one patient and no cases of increased levels of hemoglobin, hematocrit or mean corpuscular volume were found. Pancreatitis, bone fractures and nephrolithiasis were not found. Other metabolic imbalances occurred as depicted in Table 5 .

Of the eighteen patients who ceased KD, seven patients (38.9\%) did a screening for persistent abnormal laboratory tests after the end of treatment: 6/7 had hypercholesterolemia which disappeared in five, $5 / 7$ had hypertriglyceridemia which disappeared in four and 4/7 had hyperuricemia which disappeared in all of them.

\section{DISCUSSION}

The mean age of initiation of KD therapy, seven yearsold, was similar to what is described by other groups (who also follow the guidelines of the International Ketogenic Diet Study Group). This is understandable since KD is still not seen as a first line therapy for childhood epilepsy, and is

Table 3 - Efficacy by electroclinical diagnosis (ILAE classification), in the 29 patients on KD for more than three months

\begin{tabular}{|c|c|c|c|c|c|c|c|c|c|c|c|}
\hline & & $\begin{array}{l}\text { Lennox- } \\
\text { Gastaut } \\
\text { syndrome } \\
(n=9)\end{array}$ & $\begin{array}{c}\text { West } \\
\text { syndrome } \\
(n=7)\end{array}$ & $\begin{array}{l}\text { Epilepsy with } \\
\text { myoclonic- } \\
\text { atonic } \\
\text { seizures } \\
(\mathrm{n}=4)\end{array}$ & $\begin{array}{l}\text { Ohtahara } \\
\text { syndrome } \\
(n=2)\end{array}$ & $\begin{array}{c}\text { Myoclonic } \\
\text { epilepsy } \\
\text { in infancy } \\
(n=2)\end{array}$ & $\begin{array}{l}\text { Landau- } \\
\text { Kleffner } \\
\text { syndrome } \\
(n=1)\end{array}$ & $\begin{array}{c}\text { Dravet } \\
\text { syndrome } \\
(n=1)\end{array}$ & $\begin{array}{c}\text { Tuberous } \\
\text { sclerosis } \\
\text { complex } \\
(n=1)\end{array}$ & $\begin{array}{l}\text { Gener- } \\
\text { alized } \\
\text { absence } \\
\text { epilepsy } \\
(n=1)\end{array}$ & $\begin{array}{r}\text { FIRES }+ \\
(n=1)\end{array}$ \\
\hline \multirow{5}{*}{$\begin{array}{l}\text { Seizure } \\
\text { reduction } \\
\text { rate }\end{array}$} & $100 \%$ & 3 & 0 & 1 & 0 & 0 & 0 & 0 & 0 & 0 & 0 \\
\hline & $>90 \%$ & 1 & 1 & 1 & 0 & 0 & 1 & 0 & 0 & 0 & 0 \\
\hline & $50 \%-90 \%$ & 3 & 2 & 2 & 1 & 0 & 0 & 1 & 0 & 0 & 1 \\
\hline & $<50 \%$ & 1 & 2 & 0 & 0 & 1 & 0 & 0 & 1 & 0 & 0 \\
\hline & $0 \%$ & 1 & 2 & 0 & 1 & 1 & 0 & 0 & 0 & 1 & 0 \\
\hline \multirow{3}{*}{$\begin{array}{l}\text { Improve- } \\
\text { ment in } \\
\text { awareness }\end{array}$} & Marked & 7 & 5 & 3 & 1 & 0 & 1 & 1 & 1 & 0 & 0 \\
\hline & Moderate & 1 & 1 & 1 & 0 & 2 & 0 & 0 & 0 & 1 & 1 \\
\hline & None & 1 & 1 & 0 & 1 & 0 & 0 & 0 & 0 & 0 & 0 \\
\hline \multirow{3}{*}{$\begin{array}{l}\text { Improve- } \\
\text { ment in } \\
\text { behaviour }\end{array}$} & Marked & 6 & 5 & 4 & 1 & 0 & 1 & 1 & 0 & 0 & 0 \\
\hline & Moderate & 2 & 0 & 0 & 0 & 2 & 0 & 0 & 1 & 1 & 1 \\
\hline & None & 1 & 2 & 0 & 1 & 0 & 0 & 0 & 0 & 0 & 0 \\
\hline
\end{tabular}

†FIRES: febrile infection-related epilepsy syndrome 
Table 4 - Efficacy by pathogenic mutations and chromosome abnormalities identified in seven of the 29 patients

\begin{tabular}{|c|c|c|c|c|c|c|c|c|}
\hline & & $\begin{array}{c}\text { SYNGAP1 } \\
\text { gene** } \\
(n=1)\end{array}$ & $\begin{array}{l}\text { SCN9A } \\
\text { gene** } \\
(n=1)\end{array}$ & $\begin{array}{c}\text { TSC1 } \\
\text { gene** } \\
(n=1)\end{array}$ & $\begin{array}{l}\text { MAG/2 } \\
\text { gene** } \\
(n=1)\end{array}$ & $\begin{array}{c}\text { LIS } \\
\text { gene } \\
(n=1)\end{array}$ & $\begin{array}{c}\text { Tetrasomy } \\
15 q \\
(n=1)\end{array}$ & $\begin{array}{c}d e l \\
22 q 11.21^{* *} \\
(n=1)\end{array}$ \\
\hline \multirow{5}{*}{$\begin{array}{l}\text { Seizure } \\
\text { reduction rate }\end{array}$} & $100 \%$ & & & & & & & $x$ \\
\hline & $>90 \%$ & $x$ & & & & & & \\
\hline & $50 \%-90 \%$ & & $x$ & & & $x$ & $x$ & \\
\hline & $<50 \%$ & & & $x$ & $x$ & & & \\
\hline & $0 \%$ & & & & & & & \\
\hline \multirow{3}{*}{$\begin{array}{l}\text { Improvement in } \\
\text { awareness }\end{array}$} & Marked & $x$ & & $x$ & & $x$ & $x$ & $x$ \\
\hline & Moderate & & $x$ & & $x$ & & & \\
\hline & None & & & & & & & \\
\hline \multirow{3}{*}{$\begin{array}{l}\text { Improvement in } \\
\text { behaviour }\end{array}$} & Marked & $x$ & & & & $x$ & $x$ & $x$ \\
\hline & Moderate & & $x$ & $x$ & & & & \\
\hline & None & & & & $x$ & & & \\
\hline
\end{tabular}

**del: deletion; LIS: lissencephaly; MAGI2: membrane-associated Guanylate kinase inverted 2; SCN9A: sodium voltage-gated channel alpha subunit 9 (FIRES); TSC1: tuberous sclerosis 1; SYNGAP1: synaptic Ras GTPase activating protein 1.

only considered in cases of refractory epilepsy. ${ }^{5,12}$ Evidence of KD safety and efficacy in infants and younger children is growing, with the particularity of being better accepted before the introduction of solid food. ${ }^{11,15}$ In 2015, Dressler et al highlighted the efficacy of KD in infants with spasms, myoclonic astatic epilepsy and focal epilepsy. ${ }^{15,16}$

Like in most centers, the majority of our patients (25/29; $86.2 \%$ ) started KD as inpatients. ${ }^{10,12,17}$ This allowed not only to closely monitor for acute complications and its management but also a fine tuning of KD, which explained why there were different diet ratios at discharge.

Recently attention has been paid to ketogenic parenteral nutrition. We had one patient with FIRES, which began KD in the Intensive Care Unit. There were no adverse events, as reported by Dressler et al. ${ }^{18}$ FIRES is a good candidate for $K D$, as reported by various authors. ${ }^{10,19-21}$

Table 5 - Acute and chronic adverse effects of KD $(n=29)$

\begin{tabular}{lc}
\hline Acute adverse effects & No. (Total 26) ๆTा \\
\hline Hypoglycemia & 6 \\
Nausea / vomiting & 5 \\
Lethargy & 4 \\
Acidosis & 3 \\
Food refusal & 2 \\
\hline Chronic adverse effects & 23 \\
Hypercholesterolemia & 21 \\
Hypertriglyceridemia & 14 \\
Hypercalciuria & 12 \\
Hyperuricemia & 10 \\
Hyperphosphatemia & $9 / 1$ \\
Constipation / de novo & 9 \\
Urine crystals & 7 \\
Hypercalcemia & 6 \\
Carnitine deficit & 5 \\
Hypomagnesemia & 3 \\
Zinc deficit & 2 \\
Vitamin D deficit & 2 \\
Calcium deficit & 2 \\
Hypophosphatemia & 1 \\
Anemia &
\end{tabular}

Regarding the length of KD therapy in our cohort, the median duration was close to the required minimum period of 18 months. Considering those who ceased KD (18/29; $62.1 \%$ ), the retention rate at 12 months was $77.8 \%$. Ten children completed at least 18 months of KD, other eight stopped before completing the protocol. The rate of patients who completed the diet was similar to that described by Hallböök T et al, $55.6 \%$ vs $37.1 \%$, and was higher than in the study reported by Vehmeijer FOL et al, (18.6\%). The retention rate at 12 months was higher than in the study by Wijnen BFM et al (77.8\% vs 54\%). ${ }^{12,13,22}$

Familiar decision $(n=5)$ and inefficacy $(n=3)$ were the most frequent reasons for stopping KD. In the evaluation of KD candidates, focus on family motivation and capacity is mandatory, since these are key conditions for diet compliance.

The time-consuming and effort-intensive characteristics of the KD possibly explain the large drop-out rate in the study by Wijnen BFM et al, perhaps justifying the lack of effect of KD on quality of life..$^{12-14,23}$

It would be important to have predictors of KD efficacy, so that we could prescribe it to those who would improve, as managing the diet is more time consuming than providing AEDs. Some researchers aimed to discover a link between etiology and epilepsy-type and response to KD, but until now they have not succeeded. ${ }^{24}$ Data obtained by Hallböök et al suggested a relationship between seizure frequency before initiation and response (the best responders were those without daily seizures); Vehmeijer's group found that children with a successful response at three months were significantly more likely to achieve success at one month follow-up. ${ }^{13,23}$ Due to the limited dimension of our cohort, we cannot draw conclusions on the efficacy related to seizure reduction. However, we observed an important improvement regarding alertness and behavior, as previously described by other authors. ${ }^{10,25-27}$ This is very important to caregivers as it strengthens the relationship with their child, enabling them to enjoy their relationship and, at the same time, keep them motivated to continue with KD. 
In seventeen out of twenty-nine patients (58.6\%) there was a significant seizure decrease $(\geq 50 \%)$. Both retrospective and prospective studies have shown that more than half of the patients treated with KD therapy achieved more than $50 \%$ seizure reduction. ${ }^{1,5,22,27}$

When searching in the literature for efficacy by etiology, rewarding results were obtained with KD in Dravet syndrome (with no different response regarding the type of mutation as reported by Dressler et al), epilepsy with myoclonic-atonic seizures, tuberous sclerosis complex, but also in Otahara syndrome, Lennox-Gastaut syndrome and West syndrome..$^{10,28-31}$

The median number of AED remained equal at the end of KD (3 AED). Pasca et al highlighted the need for specific indications on how to cope with AED during KD, although different studies showed that the co-administration of AED and $K D$ seems to be safe. ${ }^{33,34}$ Studies comparing KD with long-term AED are also needed.

The most common acute complications in our cohort were hypoglycemia $(6 / 26 ; 23.1 \%)$ and nausea / vomiting $(5 / 26 ; 19.2 \%)$. In the Abigail Lin et al study, these were also the most reported adverse acute effects (representing $28 \%$ and $42 \%$, respectively). Hypoglycemia was rapidly and easily corrected in all patients in both cohorts. ${ }^{17}$

Dyslipidemia has been widely described as a frequent adverse effect of KD. Different studies have demonstrated the reversibility of these changes. Özdemir et al looked at the elastic properties of the aorta and carotid arteries of patients that received at least 12 months of KD and found no changes. Even in other studies where atheroma was described it disappeared after KD discontinuation. Dyslipidemia associated with KD also appears to have no disturbing effects on ventricular function. ${ }^{35,36}$ Not all our patients underwent laboratory tests after completing treatment. In those who did, cholesterol levels normalized in 5/6 and the triglycerides in $4 / 5$. It would be reassuring to monitor the disappearance of dyslipidemia through laboratory tests at three months after KD cessation.

It is important to reinforce that, as described in literature, the adverse effects were not the main reason for discontinuation. ${ }^{37}$

None of our patients experienced pancreatitis, hepatitis or bone fractures. In other series, nephrolithiasis was a cause for KD discontinuation. ${ }^{1,9}$ Although fourteen patients in our cohort presented hypercalciuria and nine had crystals in urine, none had to stop the diet.

In agreement with other studies, in our series, multiple mineral and vitamin imbalances were detected, as seen in Table 4. 1,38 They were addressed with appropriate supplementation and had no clinical consequences.

\section{REFERENCES}

1. Pasca L, De Giorgis V, Macasaet JA, Trentani C, Tagliabue A, Veggiotti P. The changing face of dietary therapy for epilepsy. Eur J Pediatr. 2016;175:1267-76.

2. Branco AF, Ferreira A, Simões RF, Magalhães-Novais S, Zehowski C, Cope E, et al. Ketogenic diets: from cancer to mitochondrial diseases and beyond. Eur J Clin Invest. 2016;46:285-98.
Contrary to the recently published study by Kose et al, we did not find increased levels of hemoglobin, hematocrit, mean corpuscular volume and vitamin B12. We have only detected anemia in one patient. ${ }^{39}$

In 2009, Marçal M et al published a study on the effects of KD in twenty-seven Portuguese epileptic children. This study, which was until now the only paper about KD use in Portuguese children, showed favorable results in refractory epilepsy. ${ }^{40}$ By that time, the protocol in use was different, for example, the patients had to undergo an initial fasting period that is no longer used. They also evaluated behavior and cognition with similar results. We felt it was important to report our results, since they may be helpful to inform treatment of these rare conditions where there are few patients described, namely with similar kinds of mutations.

The main limitations of the present study are its retrospective nature and the reduced number of cases of each etiology. The fact that two of the main variables analyzed are subjective (awareness and behavior) can also be considered as a limitation.

\section{CONCLUSION}

$\mathrm{KD}$ is a therapeutic weapon for refractory childhood epilepsy/EE and should be considered earlier in the treatment schedule of selected epileptic syndromes as LennoxGastaut syndrome and West syndrome. The effects of KD are not limited to seizure control, and also include improvement of behavior and awareness.

Some aspects of our daily practice may be improved like the choice of KD therapy that better fits a specific patient and family and the way KD is introduced to families, which needs to be more appealing in order to increase adherence.

\section{PROTECTION OF HUMANS AND ANIMALS}

The authors declare that the procedures were followed according to the regulations established by the Clinical Research and Ethics Committee and to the Helsinki Declaration of the World Medical Association.

\section{DATA CONFIDENTIALITY}

The authors declare having followed the protocols in use at their working center regarding patients' data publication.

\section{CONFLICTS OF INTEREST}

The authors declare they have no conflicts of interest for this manuscript.

\section{FUNDING SOURCES}

This research received no specific grant from any funding agency in the public, commercial, or not-for-profit sectors.

3. Roehl K, Sewak SL. Practice paper of the Academy of Nutrition and Dietetics: classic and modified ketogenic diets for treatment of epilepsy. J Acad Nutr Diet. 2017;117:1279-92.

4. Kim JA, Yoon JR, Lee EJ, Lee JS, Kim JT, Kim HD, et al. Efficacy of the classic ketogenic and the modified Atkins diets in refractory childhood epilepsy. Epilepsia. 2016;57:51-8. 
5. Martin K, Jackson CF, Levy RG, Cooper PN. Ketogenic diet and other dietary treatments for epilepsy. Cochrane Database Syst Rev. 2016;2:CD001903.

6. Boison D. New insights into the mechanisms of the ketogenic diet. Curr Opin Neurol. 2017;30:187-92.

7. Rho JM. How does the ketogenic diet induce anti-seizure effects? Neurosci Lett. 2017;637:4-10.

8. Kossoff EH, Al-Macki N, Cervenka MC, Kim HD, Liao J, Megaw K, et al. What are the minimum requirements for ketogenic diet services in resource-limited regions? Recommendations from the International League Against Epilepsy Task Force for Dietary Therapy. Epilepsia. 2015;56:1337-42.

9. Kossoff EH, Zupec-Kania BA, Amark PE, Ballaban-Gil KR, Christina Bergqvist AG, Blackford R, et al. Optimal clinical management of children receiving the ketogenic diet: recommendations of the International Ketogenic Diet Study Group. Epilepsia. 2009;50:304-17.

10. Kossof EH, Zupec-Kania BA, Auvin S, Ballaban-Gil KR, Christina Bergqvist AG, Blackford R, et al. Optimal clinical management of children receiving dietary therapies for epilepsy: updated recommendations of the International Ketogenic Diet Study Group. Epilepsia Open. 2018;3:175-92

11. van der Louw E, van den Hurk D, Neal E, Leiendecker B, Fitzsimmon G Dority L, et al. Ketogenic diet guidelines for infants with refractory epilepsy. Eur J Paediatr Neurol. 2016;20:798-809.

12. Hallböök T, Sjölander A, Åmark P, Miranda M, Bjurulf B, Dahlin M Effectiveness of the ketogenic diet used to treat resistant childhood epilepsy in Scandinavia. Eur J Paediatr Neurol. 2015;19:29-36.

13. Wijnen BF, de Kinderen RJ, Lambrechts DA, Postulart D, Aldenkamp AP, Majoie $\mathrm{MH}$, et al. Long-term clinical outcomes and economic evaluation of the ketogenic diet versus care as usual in children and adolescents with intractable epilepsy. Epilepsy Res. 2017;132:91-9.

14. Rezaei S, Abdurahman AA, Saghazadeh A, Badv RS, Mahmoud M. Short-term and long-term efficacy of classical ketogenic diet and modified Atkins diet in children and adolescents with epilepsy: a systematic review and meta-analysis. Nutr Neurosci. 2017;25:1-18.

15. Dressler A, Trimmel-Schwahofer P, Reithofer E, Gröppel G, Mühlebner A Samueli S, et al. The ketogenic diet in infants - advantages of early use. Epilepsy Res. 2015;116:53-8.

16. Prezioso G, Carlone G, Zaccara G, Verrotti A. Efficacy of ketogenic diet for infantile spasms: a systematic review. Acta Neurol Scand 2018;137:4-11

17. Lin A, Turner Z, Doerrer SC, Stanfield A, Kossoff EH. Complications during ketogenic diet initiation: prevalence, treatment, and influence on seizure outcomes. Pediatr Neurol. 2017;68:35-9.

18. Dressler A, Haiden N, Trimmel-Schwahofer P, Benninger F, Samueli S, Gröppel G, et al. Ketogenic parenteral nutrition in 17 pediatric patients with epilepsy. Epilepsia Open. 2018;3:30-9.

19. Gaspard N, Hirsch LJ, Sculier C, Loddenkemper T, van Baalen A, Lancrenon J, et al. New-onset refractory status epilepticus (NORSE) and febrile infection-related epilepsy syndrome (FIRES): state of the art and perspectives. Epilepsia. 2018;59:745-52.

20. Farias-Moeller R, Bartolini L, Pasupuleti A, Brittany Cines RD, Kao A, Carpenter JL. A practical approach to ketogenic diet in the pediatric intensive care unit for super-refractory status epilepticus. Neurocrit Care. 2017;26:267-72.

21. Lambrechts DA, de Kinderen RJ, Vies JS, de Louw AJ, Aldenkamp $\mathrm{AP}$, Majoie HJ. A randomized controlled trial of the ketogenic diet in refractory childhood epilepsy. Acta Neurol Scand. 2017;135:231-9.

22. Vehmeijer FO, van der Louw EJ, Arts WF, Catsman-Berrevoets CE,
Neuteboom RF. Can we predict efficacy of the ketogenic diet in children with refractory epilepsy? Eur J Paediatr Neurol. 2015;19:701-5.

23. Wu YJ, Zhang LM, Chai YM, Wang J, Yu LF, Li WH, et al. Six-month efficacy of the Ketogenic diet is predicted after 3 months and is unrelated to clinical variables. Epilepsy Behav. 2016;55:165-9.

24. Zhu D, Wang M, Wang J, Yuan J, Niu G, Zhang G, et al. Ketogenic diet effects on neurobehavioral development of children with intractable epilepsy: a prospective study. Epilepsy Behav. 2016;55:87-91.

25. Hallböök T, Ji S, Maudsley S, Martin B. The effects of the ketogenic diet on behavior and cognition. Epilepsy Res. 2012;100:304-9.

26. Garcia-Penas JJ. Epilepsy, cognition and ketogenic diet. Rev Neurol. 2018;66:S71-5.

27. Baby N, Vinayan KP, Pavithran N, Grace Roy A. A pragmatic study on efficacy, tolerability and long term acceptance of ketogenic diet therapy in 74 South Indian children with pharmacoresistant epilepsy. Seizure. 2018:58:41-6.

28. Nangia S, Caraballo RH, Kang HC, Nordli DR, Scheffer IE. Is the ketogenic diet effective in specific epilepsy syndromes? Epilepsy Res. 2012;100:252-7.

29. Dressler A, Trimmel-Schwahofer P, Reithofer E, Mühlebner A, Gröppel G, Reiter-Fink E, et al. Efficacy and tolerability of the ketogenic diet in Dravet syndrome - comparison with various standard antiepileptic drug regimen. Epilepsy Res. 2015;109:81-9.

30. De Lucia S, Pichard S, llea A, Greneche MO, François L, Delanoë C, et al. An unfortunate challenge: ketogenic diet for the treatment of Lennox-Gastaut syndrome in tyrosinemia type 1. Eur J Paediatr Neurol. 2016;20:674-7.

31. Hussain SA, Shin JH, Shih EJ, Murata KK, Sewak S, Kezele MM, et al. Limited efficacy of the ketogenic diet in the treatment of highly refractory epileptic spasms. Seizure. 2016;35:59-64.

32. Appavu B, Vanatta L, Condie J, Kerrigan JF, Jarrar R. Ketogenic diet treatment for pediatric super-refractory status epilepticus. Seizure. 2016;41:62-5.

33. Bergqvist AG. Long-term monitoring of the ketogenic diet: Do's and don'ts. Epilepsy Res. 2012;100:261-6.

34. Spilioti M, Pavlou E, Gogou M, Katsanika I, Papadopoulou-Alataki E Grafakou O, et al. Valproate effect on ketosis in children under ketogenic diet. Eur J Paediatr Neurol. 2016;20:555-9.

35. Ozdemir R, Kucuk M, Guzel O, Karadeniz C, Yilmaz U, Mese T. Does ketogenic diet have any negative effect on cardiac systolic and diastolic functions in children with intractable epilepsy?: One-year follow-up results. Brain Dev. 2016;38:842-7.

36. Özdemir R, Güzel O, Küçük M, Karadeniz C, Katipoglu N, Yilmaz Ü, et al. The effect of the ketogenic diet on the vascular structure and functions in children with intractable epilepsy. Pediatr Neurol. 2016;56:30-4.

37. Cai QY, Zhou ZJ, Luo R, Gan J, Li SP, Um DZ, et al. Safety and tolerability of the ketogenic diet used for the treatment of refractory childhood epilepsy: a systematic review of published prospective studies. World $\mathrm{J}$ Pediatr. 2017;13:528-36.

38. Neal EG, Zupec-Kania B, Pfeifer HH. Carnitine, nutritional supplementation and discontinuation of ketogenic diet therapies. Epilepsy Res. 2012;100:267-71.

39. Kose E, Guzel O, Arslan N. Analysis of hematological parameters in patients treated with ketogenic diet due to drug-resistant epilepsy. Neurol Sci. 2018;39:85-9.

40. Marçal M, Deuchande S, Lima S, Vale G, Alves E, Ferreira JC, et al. Dieta cetogénica. a experiência de um serviço de pediatria. Acta Pediatr Port. 2009;40:116-9. 